\title{
MODELING CONSTRUCT OF TECHNICAL TERMINOLOGY VALUING IN THE ROMANIAN LANGUAGE BY ALLOPHONE STUDENTS
}

\author{
Mariana Golovaci*, ORCID ID: 0000-0002-0929-9200 \\ Technical University of Moldova, Ștefan cel Mare str. 168, Chișinău, Republic of Moldova \\ *mariana.golovaci@lm.utm.md
}

Received: 03. 15. 2021

Accepted: 05. 12. 2021

\begin{abstract}
The aim of the article is to reflect the theoretical premises in the construction of the specific model of technical terminology exploitation in the Romanian language by allophone students. The theoretical and practical studies devoted to professional languages, mentioned in this paper, have been fundamental elements of the pedagogical model developed for the objective of the research. The models reflected in the Common European Framework of Reference for languages, designed for formative actions, which constitute a privileged opening in supporting the formation of communicative competence in a language other than the mother tongue, served as the basis: Model of development of generalindividual competences; Model of extension and diversification of linguistic communicative competence; Model of performing the determined communicative activity (-ies); Model of optimal functional insertion in a particular domain; Model of enrichment/diversification of strategies in terms of performing tasks. Communicative competence is a category that reflects the authors' point of view equating communicative competence and terminological competence, element in the reference system ofprofessional and personal training purposes. In conclusion, the modeling construct represented in Figure 3 defines the plan to affirm the coordinates of the methodology for valuing technical terminology in higher education (formative and operational), which will be concretized at the level of performance achieved at graduation integrating the technical terminology into a message for various communication contexts.
\end{abstract}

Keywords: technical terminology, communication competence, terminological competence, didactic methodology, Pedagogical Model.

Rezumat. Scopul articolului vizează reflectarea premiselor teoretice în construcția Modelului pedagogic de valorificare a terminologiei tehnice în limba româna de către studenţii alolingvi. Studiile teoretice și practice consacrate limbajelor profesionale, menționate în prezentul articol, au constituit repere de fundamentare ale Modelului pedagogic elaborat în scopul cercetării. Drept bază au servit modelele reflectate în Cadrul european comun de referinţă pentru limbi, concepute în acţiuni formative, ce constituie o deschidere privilegiată în susţinerea formării competenţei de comunicare într-o altă limbă decât cea maternă: Modelul de dezvoltare a competenţelor generale individuale; Modelul extinderii și diversificării competenţei de comunicare lingvistică; Modelul realizării unei 
(unor) activităţi comunicative determinate; Modelul inserării funcţionale optimale într-un anumit domeniu; Modelul îmbogăţirii/diversificării strategiilor în termeni de îndeplinire a sarcinilor. Competenţa de comunicare reprezintă o categorie ce reflectă punctul de vedere al autorilor în echivalarea competenței de comunicare și a competenţei terminologice, element în sistemul de referinţă al finalităţilor de formare profesională şi personală. În concluzie, constructul modelic reprezentat în figura 3 definește planul de afirmare a coordonatelor metodologiei de valorificare a terminologiei tehnice în învăţământul superior (formativă și operațională), fapt ce va fi concretizat în nivelul de performanţă atins la absolvire privind gradul de integrare a terminologiei tehnice într-un mesaj pentru diverse contexte de comunicare.

Cuvinte-cheie: terminologie tehnică, competenţa de comunicare, competenţa terminologică, metodologia didactică, Model pedagogic.

\section{Introducere}

Optimizarea didacticii universitare în scopul dezvoltării competenței de comunicare profesională reprezintă unul din obiectivele de bază a învățământului superior, interesul științific al cercetătorilor fiind concentrat în mare parte pe dezvoltarea la nivel înalt a competenței de utilizare a lexicului specialitate. Perspectiva metodologică a valorificării terminologiei tehnice în limba româna de către studenţ̧ii alolingvi este argumentată de terminologia tehnică, un concept fundamentat teoretic la nivelul limbajului specializat, fiind parte a cercetărilor actuale care promovează ideea, că terminologia are ca „obiectiv primordial, asigurarea univocităţii transferului de cunoştinţe între specialişti, relevând capacitatea limbii de a răspunde provocărilor modernităţii fără intermediari” [1].

Corelată cu principiile terminologiei actuale, valorificarea terminologiei într-o limbă străină „exprimă cultura societăţii informaţionale, globalizată, postmodernă, care solicită cunoaşterea limbilor străine ca resursă de „îmbogăţire şi extindere a propriului spaţiu de expresie şi reprezentare"; deschidere faţă de alte sisteme de organizare socială, dar şi ca „dimensiune direct responsabilă de integrarea socială a individului şi de succesul său profesional" [2], constituind un instrument de eliminare a ambiguităţii în comunicarea ştiinţifică” [3]. Oportunitatea cercetării metodologiei date derivă din preocupările sporite pentru lexicul de specialitate, atestând studii teoretice și practice valoroase realizate în $\mathrm{R}$. Moldova, consacrate limbajelor profesionale din diverse domenii de activitate. Contribuții importante privind dezvoltarea competenţei de lectură a textelor de specialitate în limba germană la profilul ştiinţe economice sunt recunoscute în cercetarea realizată de N. Barbaroș (2018) [4].; dezvoltarea lexicului de specialitate înlimba engleză la studenţii economişti- A. Ixari (2013) [5]; formarea limbajului scris la studenţii facultăţilor de educaţie fizică şi sport - M. Timuș; formarea limbajului profesional la studenţii colegiului de medicină - Botnarciuc L. (2007) [6];: Afixarea în metalimbajul tehnic englez (domeniul tehnicii de telecomunicaţii)Caterenciuc S. [7]. Importanţa limbajului individual al studentului alolingv în limba română este prezentată prin abordarea implicativă a situaţiei de discurs, D. Usaci (2006) [8], analizând problema particularităţilor verbale individuale în perspectiva educaţiei lingvistice a studenţilor alolingvi în baza limbii române. Nivelul de însuşire a limbii este determinat, în mare parte, de circumstanţele consemnate de situaţia de discurs şi de posibilităţile individuale de acumulare a informaţiilor necesare, unde anume situaţia transformă studentul din subiect-receptor de informaţii în subiect-locutor activ, energizând potenţele sale intelectuale şi formându-i noi experienţe de viaţă şi de învăţare a limbii [8, p. 3]. 


\section{I.Principii de învățare a limbii române de către alolingvi}

Contextul de valorificare a terminologiei tehnice în limba româna de către studenţii alolingvi reclamă sporit organizarea procesului de formare a lexicului de specialitate după anumite principii și proceduri definite de știința metodelor, aceasta constituind una din problemele cercetării. O altă problemă derivă din contradicțiile semnalate de lipsa unui Model tehnologic ce ar include componentele ce definesc reperele teoretice privind valorificarea terminologiei tehnice în limba româna de către studenţii alolingvi. Urmărind îndeplinirea obiectivelor propuse, profesorul optează pentru o anumită manieră de abordare a activităţii, pentru un model de acţiune cu valoare normativă, ce presupune două componente distincte, dar interdependente: o componentă epistemologică și una metodologică. Componenta epistemologică înglobează mecanismele operaţionale angajate în activitatea de predare-învăţare, în timp ce componenta metodologică vizează metodele, procedeele, mijloacele și formele de organizare, capabile să asigure funcţionalitatea mecanismelor operaţionale.

Principiul participării active și conştiente a studenților la propria lor formare stă la baza interesului crescut pentru strategiile ce promovează acel tip de învăţare, care este în acelaşi timp - cunoaştere şi acţiune. Poziţia intermediară în etapele acestei rezolvări implică faptul că strategiile sunt întotdeauna determinate de context şi finalităţile educaţionale. În acelaşi timp, strategiile stabilesc o modalitate clară de rezolvare, epuizând, din punct de vedere practic, partea euristică, creativă a rezolvării, fapt ce vom demonstra prin intermediul cercetării la nivelul sistemului de tranzacții conceptuale perspectivele de valorificare a terminologiei tehnice în limba româna de către studenţii alolingvi.

Despre realitatea procesului de învățămant, modul în care este realizat, preponderent în manieră clasică, E. Joița afirmă din rezultatele cercetărilor și intrepretărilor asupra predării - învățării acumulate în ultimile decenii, că acestea pătrund cu dificultate în literatura și practica pedagogică românească din multiple motive" [9, p. 21].

Activitățile de învățare derulate după modelele constructiviste cercetate de autoare, solicită coordonarea tuturor structurilor personalității (cognitiv, afectiv, motivațional, volitiv, atitudinal, aptitudinal). Fiind un demers centrat pe elev, în activitățile de învățare constructivistă cei implicați pot să întâmpine dificultăți la suprasolicitare sau la evaluări greșite datorate unor interpretări calitative subiective, totdată, E. Joița consideră că „realizarea activității de învățare poate fi obstrucționată și de factori externi acesteia, conjuncturali, circumstanțiali, de o anumită structură mentală a societății, de tipul de experiență a elevilor, dar și a profesorilor care îndrumă activitatea de învățare" [9, p. 25].

Comparația între orientarea constructivistă conturată în ultimele decenii și practicile behavioriste determinate de modelarea comportamentului din informațiile organizate în sisteme pentru a fi ușor manipulate, este prezentată de E. Joița în planul punctelor tari și a punctelor slabe cu referire la elevi și la profesori. În procesul de stabilire a metodologiei valorificării terminologiei tehnice în limba româna de către studenţii alolingvi, această comparație reprezintă un suport important privind modul de proiectare și a rezultatelor realizării obiectivelor.

O opinie interesantă în definirea competenţei privind operarea cu termenii de specialitate în comunicare este susţinută de autorii volumului Instruirea centrată pe competenţe. Cercetare - Inovare - Formare - Dezvoltare, Mândruţ O., Catană L., Mândruţ M. $[10$, p. 31]. 


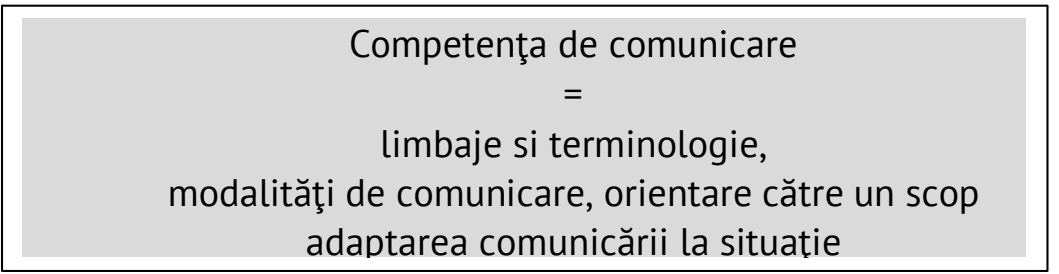

Figura 1. Incursiuni în afirmarea competenţei terminologice (după Mândruţ O., Catană L., Mândruţ M. [10, p. 31].

Competenţa de comunicare reprezintă o categorie esenţială într-o lume globală, în absenţa căreia nu se poate construi nici cunoaştere/ învăţare, nici relaţionare. Este un element cheie pentru reuşita persoanei în situaţii de viaţă, în familie, în timpul liber etc. și pentru dezvoltarea altor competenţe cheie.

Această definiţie exprimă punctul de vedere a autorilor prin care echivalează competenţa de comunicare și competenţa terminologică prin sensul grafic al parantezelor ce redau sensul de "a izola o precizare" - notă din DEX şi a interpretărilor susţinute de argumentele analizate ulterior.

Afirmaţiile prezentate cu privire la competenţa de comunicaresunt evidenţiate de pluridimensionalismul comunicării și a competenţei de comunicare:

- în limba maternă, prin cunoasterea și utilizarea limbii materne în situaţii diverse, în scris sau oral, alt aspect este o atitudine ce constă în dorinţa de a interacţiona cunoscand elementele de interculturalitate. Această competenţă este definită prin caracteristica sa de evoluţie continuă atat în mediul familial, în scoală, în mediile profesionale sau în timpul liber.

- în limbi străine, prin capacitatea de a inţelege, exprima și interpreta concepte, ganduri, sentimente, fapte și opinii oral sau în scris (ascultare, vorbire, citire și scriere), intrun număr corespunzător de contexte sociale și culturale (în educaţie și formare, la muncă, acasă și timp liber), în acord cu o dorinţă sau necesitate.

În viziunea autorilor competenţa de comunicare în limba maternă este alcătuită dintr-un ansamblu de elemente componente, referitoare la:

- utilizarea limbajului ca instrument de comunicare orală și scrisă;

- reprezentarea, interpretarea și înţelegerea realităţii utilizând ca instrument limba;

- receptarea și comunicarea cunoştinţelor;

- organizarea şi orientarea sau modelarea gândirii și a comportamentelor.

Aceasta reflectă capacitatea de a exprima și de a interpreta concepte, convingeri, sentimente și opinii, atât oral, cât și în scris; dar şi disponibilitatea de a interacţiona cu alţii intr-un mod adecvat și creativ.

Competenţa de comunicare în limbi străine variază între cele patru dimensiuni (ascultare, vorbire, citire și scriere) ca nivel de competenţă individual, pentru fiecare limbă străină în parte, în funcţie de fondul social și cultural personal, solicitând, de asemenea, aptitudini cum ar fi medierea și inţelegerea interculturală [11, p. 31].

Un alt argument prezentat de autori vizează "elementele componente ale competenţei de comunicare". Legătură între tipurile principale de activităţi (presupuse de această competenţă) și activităţile de învăţare corespunzătoare sunt inserate de autorii menţionaţi într-un tabel, elaborate pe baza operaţiilor la nivel de cunoastere, inţelegere, argumentare, luarea deciziei, rezolvare de probleme, acţiune, producerea inovaţiei, evaluare critică. 


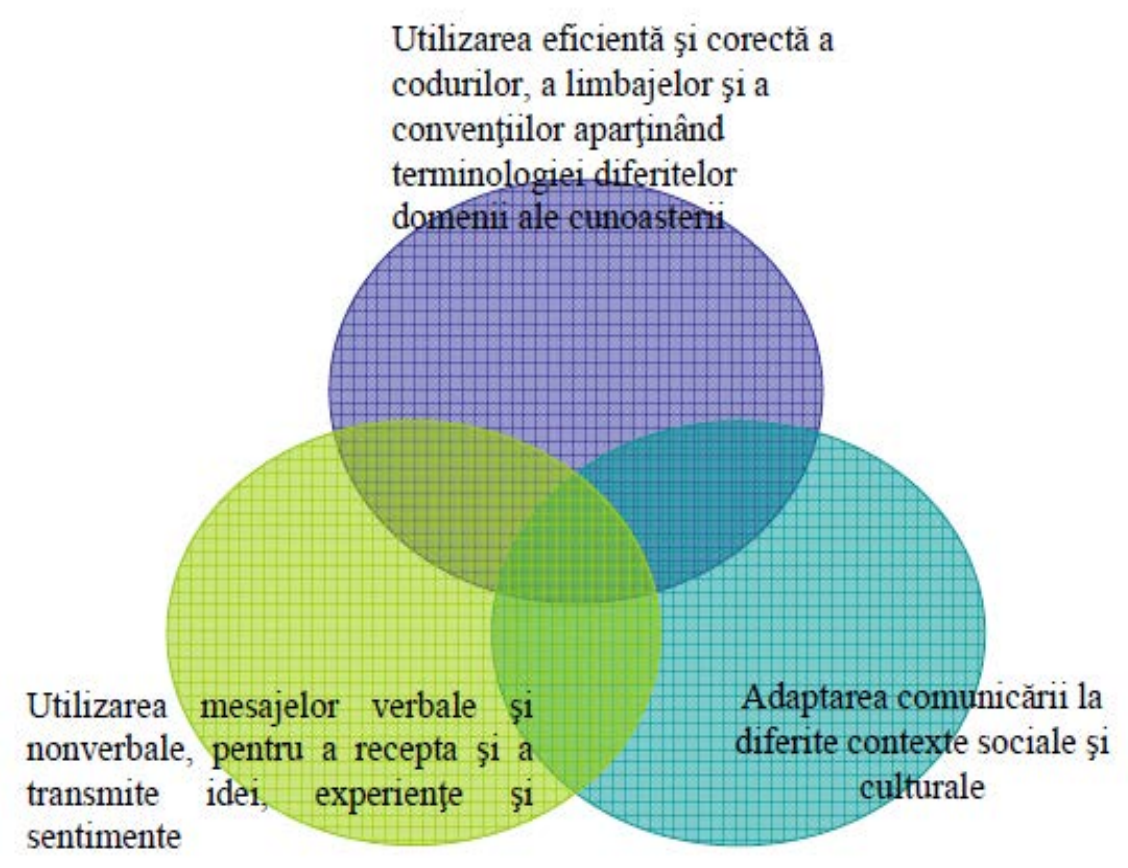

Figura 2. Expresia grafică a competenţei de comunicare (după Mândruţ [10, p. 31].

Această dimensionare reflectă taxonomia domeniului cognitiv elaborată de B.S. Bloom, ce se constituie drept cadru de referinţă posibil de adaptat la structura particulară a disciplinelor de învăţămînt. "A proiecta obiectivele conform acestei taxonomii înseamnă a lua în considerare dimensiunile informativă și formativă a educaţiei și a specifica comportamente cognitive adecvate pentru fiecare clasă de obiective (în total 6 criterii). Pentru fiecare categorie taxonomică sunt indicate tipuri reprezentative de obiective. De exemplu, înţelegerea presupune: reformularea unui enunţ de către elev/student cu propriile cuvinte, interpretarea (rezumarea, comentarea etc.) şi extrapolarea (specifică consecinţelor unui enunţ dincolo de context sau cadru de prezentare)".

Ajustarea tabelului elaborat de autorii volumului Instruirea centrată pe competenţe. Cercetare - Inovare - Formare - Dezvoltare (Mândruţ O., Catană L., Mândruţ M.) la taxonomia domeniului cognitiv (B.S. Bloom) este redată în cercetarea de faţă în tabelul ce urmează:

Tabelul 1

\section{Abordarea competenţei de comunicare (terminologice) în planul obeictivelor cognitive}

\begin{tabular}{|c|c|c|}
\hline $\begin{array}{l}\text { COMPETENTE VIZATE } \\
\text { (după Cristea S.) }\end{array}$ & & $\begin{array}{l}\text { Competența de comunicare } \\
\text { Mândruţ O., Catană L., Mândruţ M) }\end{array}$ \\
\hline $\begin{array}{l}\text { 1. cunoastere (date, termeni, } \\
\text { clasificări, metode, teorii, } \\
\text { categorii) }\end{array}$ & cunoastem & $\begin{array}{l}\text { - identificăm termeni } \\
\text { - memorăm termeni noi }\end{array}$ \\
\hline $\begin{array}{l}\text { 2. intelegere /capacitatea de } \\
\text { raportare a noilor cunoştinţe la } \\
\text { cunoştinţele anterioare prin: } \\
\text { - } \quad \text { traducere } \\
\text { - } \quad \text { interpretare } \\
\text { extrapolare }\end{array}$ & inţelegem & $\begin{array}{l}\text { - utilizăm limbajul ca un instrument } \\
\text { pentru construirea cunoasterii } \\
\text { individuale } \\
\text { - inţelegem mesaje : cerințe, scopuri, } \\
\text { opţiuni etc. }\end{array}$ \\
\hline
\end{tabular}


Continuare Tabelul 1

3. aplicare (a noilor cunoştinţe)

argumentăm

- generăm opinii diverse în legătură cu o situaţie, cu o metodă utilizată cu

o rezolvare propusă etc.

- aplicăm etape sau scheme de argumentare a poziţiei adoptate faţă de o problemă cu scopul de a convinge

4. analiza pentru:

- căutarea elementelor

- căutarea relaţiilor

- căutarea principiilor de organizare
- formulăm comenzi care orientează

acţiunea individului

- organizăm și coordonăm activitatea unui grup

- utilizăm terminologii specifice

- alegem metode și formulăm ipoteze

rezolvăm - căutăm și comunicăm soluţii atipice,

probleme căutăm rezolvări pentru cazuri

particulare, pentru generalizări

- rezolvăm un conflict

- împărtășim valori comune

- iniţiem o acţiune - finalizarea

acţiunii

- dăm feedback, realizăm aprecieri

5. sinteza pentru:

- crearea unei opere personale

- elaborarea unui plan de acţiune

- derivarea unor relaţii abstracte dintr-un ansamblu
- propunem soluţii pentru o problemă

\begin{tabular}{lll} 
luăm o & - propunem soluţii pentru o problemă \\
decizie & - apreciem avantajele și limitele \\
& soluţiilor \\
& - luăm decizii rapide, căutăm să fim \\
& eficienţi \\
\hline $\begin{array}{l}\text { producem } \\
\text { inovare }\end{array}$ & - producem texte personale \\
& -utilizăm limbajul pentru
\end{tabular}

comunicarea unor idei innovative

evaluăm

- realizăm aprecieri

critic

- argumentăm părerile personale

- critica internă

- critica externă

Învăţarea limbilor presupune alegerea între diferite tipuri și niveluri de obiective. Cadrul de referinţă reflectă cinci modele de predare-învăţare şi modul cum fiecare dintre componentele esenţiale ale modelului poate să se focalizeze asupra obiectivelor de învăţare:

1. dezvoltare a competenţelor generale individuale ale elevului

2. extindere și de diversificare a competenţei de comunicare lingvistică

3. realizări a unei (unor) activităţi comunicative determinate

4. inserare funcţională optimală într-un anumit domeniu

5. îmbogăţire sau diversificare a strategiilor sau în termeni de îndeplinire a sarcinilor

Modelele reflectate în Cadrul de referinţăse referă la diverse categorii de obiective ale predării/învăţării, care pot fi concepute în acţiuni formative, constituind o deschidere 
privilegiată în susţinerea formării competenţei de comunicare într-o altă limbă decât cea maternă. Prezentăm în continuare sinteza acestor modele din Cadrul european comun de referinţă pentru limbi: învăţare, predare, evaluare, în condiţiile determinării asupra elementelor concepute.

\section{II.Modelul valorificării terminologiei tehnice în limba româna de către alolingvi}

1. Modelul de dezvoltare a competenţelor generale individuale (vezi Secţiunea 5.1), obiectivele se referă la cunoștinţe, deprinderi (capacităţi), competenţa existenţială (trăsături de personalitate, atitudini etc.) sau capacitatea de a învăţa, ori la una din aceste dimensiuni în mod particular.

Acest model aduce în atenţie mai multe situaţii de învăţare a unei limbi străine [11, p. 111]:

- înzestrarea cu noi cunoștinţe declarative (de exemplu, despre gramatică sau literatură sau despre anumite caracteristici culturale ale unei ţări străine);

- învăţarea ca mijloc de dezvoltare a personalităţii (de exemplu, pentru mai multă siguranţă sau încredere în sine, pentru o atitudine mai degajată faţă de luările de cuvânt):

- dezvoltarea capacităţii de a învăţa (o mai mare deschidere pentru tot ce e nou, conștientizarea altor limbi și culturi, curiozitatea faţă de necunoscut).

Aceste scopuri specifice care se referă la un anumit sector sau tip de competenţă, la aplicarea sau dezvoltarea unei competenţe parţiale, permit dezvoltarea sau consolidarea unei competenţe plurilingve și pluriculturale transversale. Cu alte cuvinte, autorii PÎE consideră, că urmărirea unui obiectiv parţial își poate avea locul într-un proiect global de învăţare.

2. Modelul extinderii și diversificării competenţei de comunicare lingvistică vizează (vezi Secţiunea 5.2), obiectivele definite de 3 componente:

- componenta lingvistică,

- componenta pragmatică,

- componenta socio-lingvistică.

Învăţarea unei limbi străine în baza Modelului extinderii și diversificării competenţei de comunicare lingvistică este organizată prin construirea elementelor de învăţare fie de toate trei la un loc sau fiecare în parte.

Aşadar, Cadrul PÎE specifică următoarele variante de învăţare:

- asigurarea componentei lingvistice a unei limbi străine (cunoașterea sistemului fonetic, a vocabularului și a sintaxei acestei limbi), fără a se preocupa de fineţea sociolingvistică sau de eficacitatea pragmatică.

- asigurarea componentei pragmatice, care să corespundă capacităţii de a comunica în limba străină cu mijloace lingvistice limitate, fără să se acorde prea multă atenţie pertinenţei socio-lingvistice.

- asugurarea componentei socio-lingvistice, care insistă asupra unor norme sociolingvistice (formule de adresare, eventual folosirea persoanei a treia etc.) sau asupra anumitor norme comportamentale (discreţie de bonton, afabilitate, răbdare etc.);

- armonizarea componentelor în una prin exemple de obiective orientate spre una sau alta dintre componentele competenţei de comunicare lingvistică, fiind cea concepută ca o competenţă plurilingvă și pluriculturală, ce prezintă un tot întreg (comportând adică mai multe varietăţi ale limbii materne și varietăţi ale uneia sau mai multor limbi străine). 
3. Modelul realizării unei (unor) activităţi comunicative determinate (vezi Secţiunea 4.4), obiectivele se referă la recepție, producere, interacţiune sau mediere.

La fel, ca în modelul precedent activităţile comunicative determinate din acest model (recepţie, producere, interacţiune sau mediere) pot fi organizate independent (de ex. obţinerea unor rezultate efective în activităţile de recepţie prin citire sau audiere; rezultate obţinute într-o activitate de mediere prin traducere sau interpretare) sau simultan, acordând o atenţie deosebită interacţiunii în cadrul comunicării „faţă în faţă”.

Explicaţiile aduse de Cadrul PÎE cu privire la efectuarea învăţării în baza acestui model, dau de înţeles, că nu se poate vorbi despre "polarizări absolute, în totală izolare faţă de alte scopuri. Totuși, atunci când sunt definite obiectivele, este posibil ca o anumită dimensiune să fie pusă în prim plan cu fermitate, urmând ca această prioritate majoră să influenţeze, cu condiţia că este coerentă, întregul dispozitiv de învăţare; alegerea conţinutului și a sarcinilor învăţării, determinarea structurii progresului și a modalităţilor posibile de remediere, selectarea tipurilor de texte etc. [11, p. 112].

4. Modelul inserării funcţionale optimale într-un anumit domeniu (vezi Secţiunea 4.1.1), vizează obiectivele privind învăţarea unei limbi străine cu referire la diverse domenii de activitate: public, profesional, educaţional, personal etc.

Acest model are ca obiectiv principal „o mai bună adaptare la cerinţele unui post de lucru sau la contextul unei instruiri sau la anumite condiţii ale vieţii cotidiene într-o ţară străină”. Cadrul PÎE recomandă integrarea (infuzarea) obiectivelor de învăţare a unei limbi străine în "propunerile de curs, în cererile și ofertele în materie de instruire, în materialele didactice publicate". Strategiile de realizare a acestor activităţi sunt definite de următoarele forme:

- „obiective specifice”;

- „cursuri de limbă de specialitate”,

- „cursuri de limbă pentru diferite profesiuni”,

- pregătirea pentru șederea în străinătate”,

- cursuri de limbă pentru muncitorii migratori”.

Ca și în cazul celorlalte componente, această formă de obiectiv de inserare funcţională într-un domeniu corespunde și situaţiilor de învăţământ bilingv, de imersiune și de profesionalizare într-o limbă diferită de cea vorbită în familie. Din acest punct de vedere, "în afara oricărui paradox în interiorul analizei de faţă, aceste situaţii de imersiune, de altfel, indiferent de rezultatele lingvistice la care acestea permit să se ajungă, vizează dezvoltarea unor competenţe parţiale: acelea care se potrivesc domeniului educaţional și însușirii unor cunoștinţe disciplinare altele decât cele lingvistice", subliniază autorii Cadrului european $[11$, p. 12].

5. Modelul îmbogăţirii/diversificării strategiilor în termeni de îndeplinire a sarcinilor, se referă la operaţionalizarea acţiunilor privind utilizarea sau învăţarea uneia sau mai multor limbi, de descoperirea sau de experienţa altor culturi. În acest model, obiectivul este orientat spre îndeplinirea unor sarcini pentru care ele nu fuseseră mobilizate initial, ridicându-le gradul de complexitate, mobilizarea competenţelor de care dispune pentru a le pune în aplicare și poate pentru a le consolida sau lărgi.

Opţiunile metodologice pentru predareași învăţarea limbilor reflectate în Cadrul european comun de referinţă pentru limbi au pus la dispoziţ̧ie modele de utilizare a limbii „cât se poate de complete, atrăgând atenţia, de-a lungul întregului parcurs, asupra pertinenţei 
diferitelor componente ale modelului de învăţare, predare și evaluare”. Această conveniență a fost considerată esenţialmente în termeni de conţinut și obiective aleînvăţării, fiind expuse pe scurt în secţiunile 6.1 și 6.2. ale ediţiei prin următoarele conţinuturi: obiectivele învăţării; gestionarea flexibilă a progresului; competenţa plurilingvă și pluriculturală; variaţia obiectivelor în raport cu cadrul de referinţă şi operaţiile de învăţare a limbilor [11, p. 108 114].

Faptul, că metodologia didactică, are ca prioritate „caracteristicile operaţionale ale metodelor”, iar funcţiile specifice evidenţiază valoarea acestora în calitate de „modele pedagogice”, situate la diferite „poluri” de referinţă, [12]. Cadrul european comun de referinţă pentru limbi sugerează modelul de utilizare a limbii la nivelul pertinenţei diferitelor componente ale modelului de învăţare, predare și evaluare [11, p. 108 - 114], este argumentată elaborarea unui model tehnologic de susţinere a metodologiei de valorificare a terminologiei tehnice în limba româna de către studenţii alolingvi.

Afirmaţiile despre oportunitatea structurării unui conţinut, demonstrează, că "oricât de oportun ar fi, acesta va înregistra întotdeauna un decalaj între ceea ce este nou şi ceea ce se oferă realmente subiecţilor în procesul de învăţare”. C. Cucos pledează pentru ca în cadrul conţinutului învăţământului, se fie realizat un "optimum între ceea ce este constant şi general în cunoaştere şi ceea ce este perisabil şi efemer”, absolut relevant contextului de dezvoltare a terminologiei.

“Centrarea conţinuturilor spre codurile de referinţă şi cele de interpretare (concepte, metodologii, teorii) asigură acestora perenitate şi consistenţă. Fixarea în conţinuturi a unor elemente conjuncturale asigură acestora un caracter adecvat, aplicabilitate şi eficienţă. Găsirea unui echilibru între cele două componente este o sarcină atât a factorilor de decizie, cât şi a educatorilor"., subliniază C. Cucos [13].

Urmărind scopul de elaborare, stabilire şi aplicare a metodelor, Modelul pedagogic care imprimă caracter operațional al metodologiei de valorificare a terminologiei tehnice în limba româna conjugă „polul psihologic” (S. Cristea) al activităţii de predare-învăţareevaluare, caracteristic funcţiei formative a metodelor didactice, cu „polul praxiologic” (S. Cristea) al activităţii de predare-învăţare-evaluare din caracteristicile funcţiei operaţionale a metodelor didactice.

Evident, afirmarea coordonatelor metodologiei de valorificare a terminologiei tehnice în învăţământul superior este asigurată de politicile instituţionale, solicitate de a răspunde beneficiarilor-absolvenţi prin abordările şi principiile generale puse în aplicare. „Digitalizarea şi extinderea tehnologiilor informaţionale şi comunicaţionale a generat schimbarea paradigmei de cunoaştere şi de formare a competenţelor, iar provocările politice/economice determină noi valenţe şi oportunităţi educaţionale, precum ar fi: educaţia pe parcursul întregii vieţi, educaţia pentru toţi şi pentru fiecare, dezvoltarea integrală şi integră a personalităţii, educaţia centrată pe cel ce învaţă etc., aspecte subliniate de autorii Cadrului de referinţă al curriculumului universitar [14, p. 5].

Metodologia de valorificare a terminologiei tehnice în limba româna de către studenţii alolingvi este parte integrantă a dezvoltării curriculumului universitarca „paradigmă şi model de proiectare a formării profesionale iniţiale şi continue" şi ca proces integrat în contextul social-economicnaţional şi internaţional. „Procesul de predare-învăţare-evaluare se desfăşoară conform metodologiei şi normelor de calitate, având în vedere următoarele componente: curricula și proiectarea didactică, managementul procesului de predareînvăţare-evaluare; strategia de predare, resursele de învăţare; stagiile de practică și 
evaluările finale”. Competenţele devin un nou sistem de referinţă al finalităţilor de formare profesională şi personală, iar conţinuturile - mijlocul de formare a acestor competenţe, racordate la necesităţile pieţii muncii [14, p. 12].

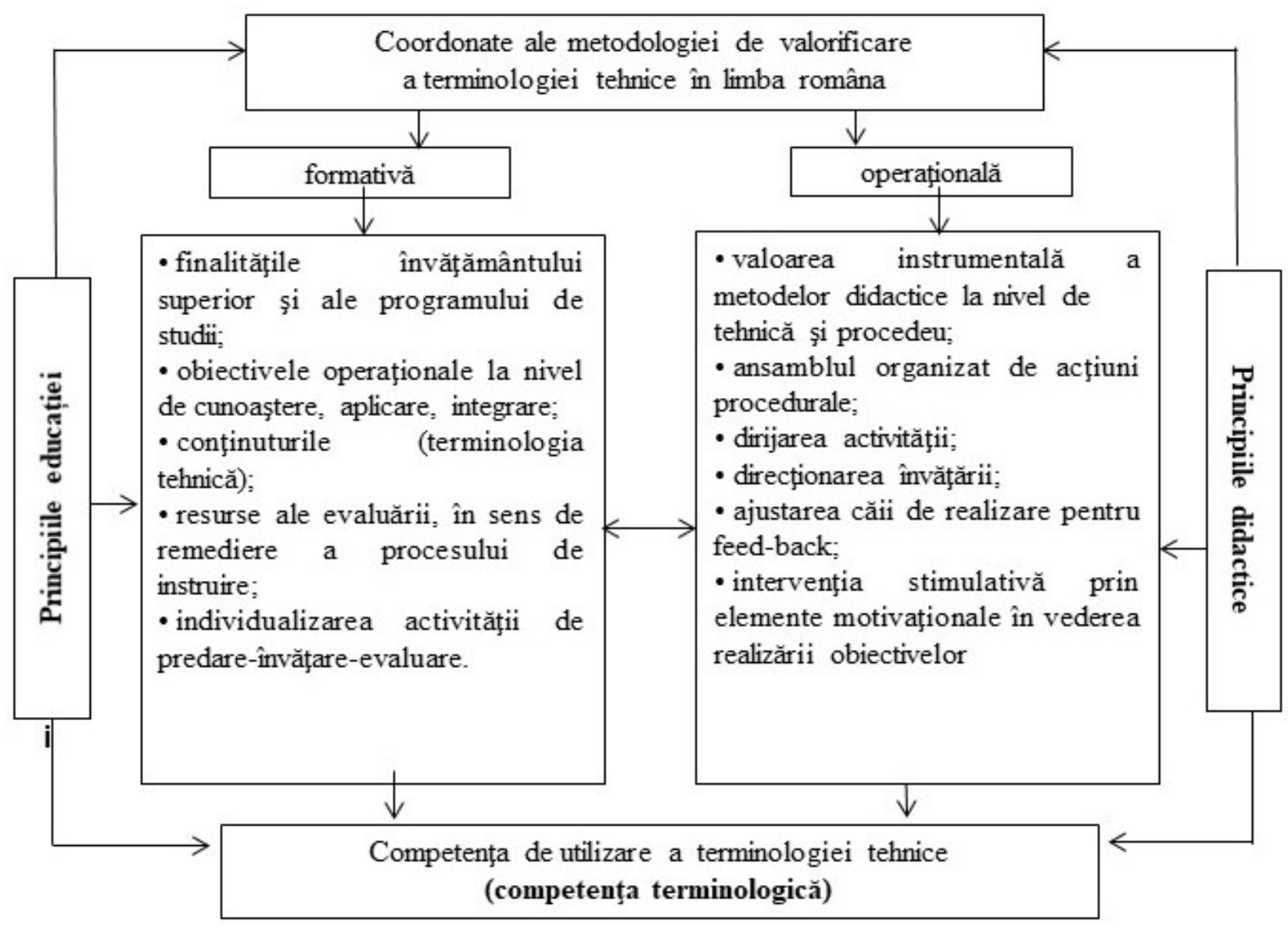

Figura 3. Coordonatele Modelului pedagogic privind metodologia de valorificare a terminologiei tehnice în învăţământul superior.

Conform principiului metodologic fundamental al Consiliului Europei, metodele care trebuie aplicate în învăţare, predare și cercetare sunt cele care sunt considerate cele mai eficace pentru atingerea obiectivelor stabilite în funcţie de subiecţii vizaţi în procesul de învăţare sau formare. Eficacitatea este subordonată motivaţiilor și caracteristicilor subiecţilor, precum și naturii resurselor umane și materiale la care se poate recurge" $[15,16]$.

\section{Concluzii}

Concluzia rezumată privind planul operațional al constructului modelic de valorificare a terminologiei tehnice în limba româna de către studenţii alolingvi este definită de finalitatea procesului de formare a competenţelor în cadrul programelor de studii din învăţământul superior tehnic, concretizat în nivelul de performanţă atins la absolvire.

Metodologia de valorificare a terminologiei tehnice în limba româna de către studenţii alolingvi este direct susţinută de calitatea procesului de formare a competenţelor în cadrul programelor de studii din învăţământul superior tehnic, asigurând condiţii de dezvoltare pentru integrarea terminologiei tehnice în diverse contexte de comunicare în limba română. 


\section{Bibliografie}

1. Grand Dictionnaire Terminologique. http://www.oqlf.gouv.qc.ca/ (vizitat 12.11.2020).

2. Avramescu A. Dicţionar cronologic al știinţei şi tehnicii universale. Bucureşti: Ed. Ştiinţifică şi Enciclopedie, 1979. $813 \mathrm{p}$.

3. Bahnaru V. (red. resp.). Lexicologia practică a limbii române. Chișinău: Î.E.P. Știința, 2013. 490 p. ISBN 978-9975-4460-4-4

4. Barbaroş N. Dezvoltarea competenţei de lectură a textelor de specialitate în limba germană (la profilul ştiinţe economice): autoref. al tezei de doct. În pedagogie. Chișinău, 2019. 30 p.

5. Ixari A. Tehnologia dezvoltării lexicului de specialitate în limba engleză la studenţii economişti. Autoreferatul tezei de doctor în pedagogie. Chişinău, 2013. 31 p.

6. Botnarciuc L. Formarea limbajului profesional la studenţii colegiului de medicină. Teză de doctor în pedagogie, Chișinău, 2007

7. Caterenciuc S. Clasificări structurale ale termenilor din domeniul telecomunicațiilor Studia Universitatis Moldaviae, 2018, nr. 4 (114) Seria "Științe umanistice" ISSN 1811-2668 ISSN, p.17-21

8. Usaci D. Dezvoltarea limbajului individual al studenţilor alolingvi în baza situaţiei de discurs". Chişinău, 2006. $172 \mathrm{p}$.

9. Joița E. Profesorul si alternative constructivistă a instruirii. Material - suport pedagogic pentru studenții viitori profesori https://docgo.net/view-doc.html?utm_source=23186428-profesorul-si-alternativaconstructivista-a-instruirii-pdf (vizitat 07.06.2020).

10. Mândruţ O., Catană L., Mândruţ M. Instruirea centrată pe competenţe. Cercetare - Inovare - Formare Dezvoltare. Arad, "Vasile Goldiş" University Press, 2012. 145 p. ISBN: 978-973-664-538-9

11. Cadrul European comun de referinţă pentru limbi: învăţare, predare, evaluare. trad. din L. fr. de Gheorghe Moldovanu. Chişinău: F.E.-P. Tipografia Centrală, 2003. 204 p. ISBN 9975-78-259-0

12. Cristea S. Dicţionar de termeni pedagogici. București: EDP, R.A., 1998, p. 302. ISBN 973-30-5130-6

13. Cucoş C. Pedagogie. Iaşi: Polirom, 1996. 230 p. ISBN: 973-9248-03-9

14. Cadrul de referinţă al curriculumului universitar (coord.: Vladimir Guțu). Chișinău: CEP USM, 2015. -128 p. ISBN 978-9975-71-689-5

15. Bidu-Vrănceanu A. (coord.). (2012 b). Terminologie și terminologii (II). București: Editura Universității din București, 2012. 248 p. ISBN 978-606-16-0095-3

16. Ciobanu G. Elemente de terminologie. Timişoara: Editura Mirton, 1998. 160 p. 